\title{
Bentuk Dan Arti Seni Hias Pada Masjid Besar Kauman Yogyakarta
}

\section{Muhammad Chawari}

Keywords: symbol, ornament, mosque, islam, java

\section{How to Cite:}

Chawari, M. (2000). Bentuk Dan Arti Seni Hias Pada Masjid Besar Kauman Yogyakarta. Berkala Arkeologi, 20(1), 110-124. https://doi.org/10.30883/jba.v20i1.811

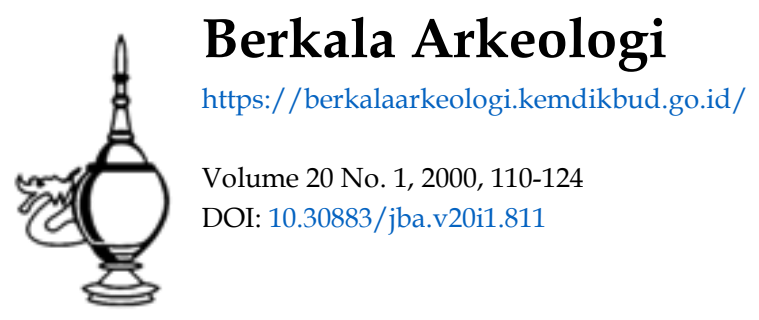

\section{(c) (i)(2)}

This work is licensed under a Creative Commons Attribution-NonCommercial-ShareAlike 4.0 International License. 


\title{
BENTUK DAN ARTI SENI HIAS \\ PADA MASJID BESAR KAUMAN YOGYAKARTA
}

\author{
Muhammad Chawari \\ (Balai Arkeologi Yogyakarta)
}

\section{Pendahuluan}

Masjid Besar Kauman Yogyakarta merupakan suatu kompleks dengan luas keseluruhan $16.000 \mathrm{~m}^{2}$ yang dipisahkan dengan daerah sekitarnya oleh pagar keliling. Bangunan masjid berdenah bujur sangkar, dan memiliki luas $2.578 \mathrm{~m}^{2}$. Bangunanbangunan yang ada terdiri atas serambi, ruang utama, bangunan samping (pawestren), dan bangunan lainnya (Atmodjo, 1999). Di dalam masjid tersebut (baik pada ruang inti maupun scrambi) banyak sekali ditemukan hiasan. Hiasan-hiasan tersebut pada umumnya dipahatkan pada tiang bangunan maupun bagian-bagian bangunan lainnya. Hiasan-hiasan tersebut mempunyai arti sebagai penghias ruangan maupun sebagai simbol tertentu yang erat kaitannya dengan agama Islam.

Selanjutnya hasil kesenian Islam yang tertua di Indonesia sampai saat ini dapat dilihat dalam seni pahat dan seni bangun, yaitu berupa nisan dan kubur. Selanjutnya muncul pula hasil seni bangun lainnya, seperti masjid. Hasil-hasil seni bangun tersebut mempunyai beberapa unsur pelengkap, misalnya hiasan-hiasan berupa pahatan maupun ukiran dengan aneka ragam corak. Melihat hasil-hasil seni bangun Islam beserta unsur pelengkapnya, akan dapat diketahui unsur-unsur yang memainkan peranan dalam pembuatannya (Abbas, 1983).

Seni hias merupakan salah satu unsur penting dalam suatu bangunan di samping seni bangun itu sendiri. Seni hias atau ornamentasi berdasarkan fungsinya dapat dibagi menjadi tiga, yaitu: applied ornament, organic ornament, dan mimetic ornament (Encyclopaedia Britanica Vol. 16, 1961). Applied ornament yaitu hiasan yang berfungsi konstruktif struktural. Maksudnya adalah bahwa hiasan menopang struktur bangunan yang biasanya digunakan pada bagian-bagian atau elemen bangunan. Organic ornament yaitu hiasan yang diterapkan pada bagian bangunan tetapi tidak menopang struktur bangunan, jadi hanya bersifat dekoratif. Sedangkan mimetic ornament yaitu hiasan yang mempunyai fungsi simbolis. Hiasan ini selain berfungsi sebagai hiasan juga mempunyai makna tertentu. Hiasan berbentuk ini dapat diterapkan pada hiasan yang bersifat konstruktif maupun dekoratif (Saptono, 1990). Sesuai dengan judul tulisan ini, maka seni hias yang akan dikemukakan meliputi ketiga seni hias seperti tersebut di atas. 
Pada umumnya orang Jawa di dalam membuat sesuatu hal atau untuk menyampaikan pesan-pesannya seringkali tidak langsung. Artinya bahwa pesan-pesan atau hal-hal yang berhubungan dengan estetika tersebut disampaikan melalui atau memakai tanda atau gambar tertentu. Pemakaian tanda-tanda tersebut berhubungan erat dengan ajaran agama Islam, mengingat gambar atau seni hias yang akan dikemukakan ini berada di dalam bangunan suci yaitu masjid. Demikian juga keberadaan seni hias yang terdapat pada Masjid Besar Kauman Yogyakarta.

Fungsi hiasan pada suatu bangunan ialah untuk memperindah atau mempercantik bangunan. Sebab keindahan yang mengagumkan biasanya dapat menyejukkan hati seseorang yang melihatnya, di samping rasa tenteram yang mendalam. Selain itu dapat juga untuk memberikan kesan sakral, terkadang malah tampak kelihatan angker. Halhal tersebut disebabkan oleh bentuk dan cara menampilkan hiasan yang dibuat.

Sesuai dengan judul, tulisan ini ingin menampilkan bentuk-bentuk hiasan dan maknanya yang terdapat pada Masjid Besar Kauman Yogyakarta. Dalam tulisan ini mungkin belum seluruh hiasan dapat ditampilkan, mengingat akan keterbatasan media, waktu, dan kemampuan yang ada.

\section{Bentuk dan Jenis Seni Hias pada Masjid Besar Kauman}

Di Masjid Besar Kauman Yogyakarta banyak ditemukan hiasan. Hiasan-hiasan tersebut kebanyakan ditampilkan dalam bentuk dua dimensi, tetapi ada juga yang ditampilkan dalam bentuk tiga dimensi. Adapun seni hias yang terdapat pada Masjid Besar ini adalah:

\section{A. Wajikan}

Hiasan wajikan di Masjid Besar Kauman Yogyakarta terdapat pada tiang di serambi, baik di bagian atas maupun bawah. Hiasan ini ada yang memakai garis tepi (lihat gambar no. 1) dan ada yang tidak. Hiasan wajikan yang terdapat di Masjid Besar tidak memakai garis tepi, sehingga kelihatan seperti tidak memakai bingkai. Pada bagian tengahnya merupakan ukiran daun-daunan yang tersusun secara memusat. Selain ukiran daun-daunan dapat juga berupa gambar bunga jika dilihat dari depan. Sebab di tengah-tengah bidang terdapat bulatan yang menyerupai bunga yang sedang mekar. Cara meletakkannya dapat berdiri dan dapat pula terlentang. Wajikan yang terdapat di masjid ini sudut bagian atas dan bawah tidak runcing tetapi tumpul, sebab bagian atas dan bawahnya terdapat garis pemisah. Ragam hias ini ditempatkan pada tiang bagian bawah di serambi bagian atas dan bawah yaitu pada saka guru, saka penanggap, dan saka panitih dengan bagian terpanjang memanjang secara horisontal, sedangkan bagian terpendek secara vertikal. Selain itu dapat pula ditempatkan pada titik-titik persilangan balok-balok kayu yang sudut menyudut pada pagar kayu bangunan. Hal 
ini dapat dilihat pada Bangsal Manis Kraton Yogyakarta. Selanjutnya hiasan ini dapat ditempatkan pula pada pintu. Jika wajikan ini ditempatkan pada pintu, maka cara mengukirnya yaitu bagian terpanjang memanjang secara vertikal, sedangkan bagian terpendek secara horisontal. Hal ini dapat dilihat pada ketiga pintu yang akan memasuki ruang inti dari arah serambi. Hanya saja wajikan pada ketiga buah pintu tersebut berukuran besar, hampir sebesar pintu itu sendiri. Wajikan hampir sebesar pintu tersebut dibagi menjadi empat bagian.

\section{B. Praba}

Hiasan praba di Masjid Besar Kauman Yogyakarta terdapat pada tiang-tiang di serambi. Ragam hias ini selain dipahatkan pada saka guru, juga terdapat pada saka penanggap maupun saka panitih. Dilihat dari letaknya terdapat pada tiang bagian bawah dan menghadap ke atas. Bentuk seperti ini terdapat pada keempat sisi masingmasing tiang. Hiasan ini merupakan ukiran relief yang timbul, di mana bentuknya melengkung tinggi dan di tengah-tengahnya (bagian atas) lancip (lihat gambar no. 2). Hiasan praba di Masjid Besar bentuknya menyerupai tlacapan. Hiasan tersebut terdiri atas tiga buah lancipan, di mana yang di tengah-tengah lebih tinggi dari dua yang di pinggir.

\section{Tlacapan}

Ragam hias tlacapan merupakan sederetan segi tiga masa kaki.Ragam hias ini di Masjid Besar Kauman Yogyakarta terdiri atas tiga buah segi tiga, di mana segi tiga yang di tengah lebih tinggi dari dua yang di pinggir. Sedangkan di tempat lain dapat terdiri atas lebih dari tiga segi tiga (lihat gambar no. 3). Selanjutnya ragam hias ini terdapat pada tiang-tiang di serambi, baik bagian atas maupun bawah. Hiasan tlacapan yang terdapat di Masjid Besar Kauman dapat polos, tetapi dapat juga di tengahnya diisi dengan hiasan daun, atau bunga-bunga yang distilir. Cara membuat hiasan ini ada dua cara, yaitu dengan dipahat atau apat juga dilukis. Kalau hiasan ini dipahat (baik pada tembok maupun kayu) akan menjadi bentuk relief.

\section{Kaligrafi}

Hiasan kaligarfi yang terdapat di Masjid Besar Kauman Yogyakarta mempunyai 3 (tiga) macam bentuk. Ketiga macam bentuk tersebut dua di antaranya dipahatkan pada tiang yang terdapat pada serambi atas dan bawah, sedangkan yang lainnya (satu buah) dipahatkan pada umpak tiang di serambi. Ketiga macam bentuk tersebut adalah:

1. Tulisan yang dibentuk seperti hiasan sulur-suluran yang terdapat pada tiang-tiang di serambi masjid, baik serambi atas maupun serambi bawah. Di mana tulisan tersebut ditulis dari kiri ke kanan yang berbentuk simetris. Sedangkan pada bagian tengah sebelah bawah berbentuk seperti panah yang menghadap ke bawah (lihat gambar no. 4). Bentuk semacam ini ada dua tempat dalam satu tiang, yaitu di sebelah atas dan sebelah bawah. Jika hiasan ini terdapat pada bagian 
tiang sebelah atas, maka bentuk seperti panah tersebut menghadap ke bawah. Sedangkan jika hiasan ini terdapat pada bagian tiang sebelah bawah, maka bentuk seperti panah tersebut menghadap ke atas.

2. Tulisan yang dibentuk seperti hiasan sulur-suluran yang terdapat pada tiang-tiang di serambi masjid, baik serambi atas maupun serambi bawah. Di mana tulisan tersebut ditulis dari kiri turun ke bawah lalu naik ke atas yang dibentuk mirip sulur-suluran yang berakhir di kanan atas. Sehingga menyerupai telunjuk jari tangan yang sedang menunjuk ke bawah (lihat gambar no. 5).

3. Hiasan berikutnya terdapat pada umpak tiang di serambi atas dan bawah. Hiasan tersebut merupakan rangkaian huruf-huruf Arab yang distilir sedemikian rupa sehingga berbentuk hiasan yang menyerupai padma. Umpak yang dihiasi ini secara horisontal dibagi dua yaitu bagian atas dan bagian bawah. Bagian yang ada di sebelah atas, hiasan yang menyerupai padma menghadap ke atas. Sebaliknya bagian yang ada di sebelah bawah, hiasan yang menyerupai padma menghadap ke bawah. Dengan demikian keduanya menyerupai cermin (lihat gambar no. 6).

\section{E. Buah Waluh}

Hiasan buah waluh ini berbeda dengan hiasan-hiasan lain seperti yang telah diuraikan di atas. Jika hiasan-hiasan tersebut di atas merupakan hiasan yang dipahat (baik pada kayu maupun batu), maka hiasan yang berupa buah waluh ini merupakan hiasan yang dibuat sedemikian rupa sehingga bentuknya mirip buah waluh sungguhan atau dibuat dalam bentuk tiga dimensi (lihat gambar no. 7). Hiasan ini ditempatkan di atas ujung pilar, tengah, pojok, dan tempat-tempat tertentu yang dianggap penting pada bangunan pagar atau tembok keliling yang akan memasuki masjid dari arah halaman masjid sebelah depan. Di dalam Masjid Besar Kauman Yogyakarta hiasan tersebut seluruhnya berjumlah 34 buah. Jumlah tersebut sudah jauh berkurang, sebab ada beberapa yang telah dihilangkan berkaitan dengan pembuatan parit keliling seperti yang terlihat sekarang ini.

\section{F. Hiasan-hiasan lain:}

\section{Hiasan Pada Mimbar}

Antara tiang penyangga kiri dan kanan maupun depan dan belakang dihubungkan dengan papan kayu jati berukir sulur-suluran, demikian juga pada bagian atasnya yang berbentuk setengah lingkaran (Atmodjo, 1999). Dengan demikian mimbar tersebut menyerupai singgasana tempat duduk seorang raja (lihat foto no. 1).

\section{Hiasan Pada Maqsura}

Terdapat hiasan ceplok bunga yang ditempatkan pada persilangan kayu (Atmodjo, 1999). Maqsura yang terdapat di masjid ini keempat dindingnya dibuat dari kayu yang disusun tidak rapat sehingga berlubang. Selain itu, pada keempat tiangnya dihiasi dengan sulur-suluran dan hiasan kaligrafi yang dibentuk menyerupai telunjuk jari tangan yang menunjuk ke bawah (lihat foto no. 2). 


\section{Hiasan Pada Mihrab}

Pada sisi kiri dan kanan atau utara dan selatan mihrab terdapat hiasan bunga (Atmodjo, 1999). Hiasan ini diukir untuk mengapit tulisan arab yang terdapat di kanan dan kiri mihrab. Di mana tulisan ini disitir dari hadis Nabi Muhammad sw. Inskripsi ini dipahatkan pada bentuk lengkung yang di bagian bawahnya diberi ornamen pepohonan (Chawari, 1989 dan lihat foto no. 3). Kemudian di bagian kanan, kiri, dan atas mihrab dihiasi dengan sulur-suluran dan potongan ayat Al-Qur'an dari Surat Ali Imran ayat 39.

\section{Hiasan di bawah pengeret}

Hiasan ini diukir pada bidang segi tiga yang terdapat di bawah pengeret dan menempel pada seluruh tiang yang terdapat di dalam ruang inti masjid. Hiasan ini berupa sulur-suluran (lihat foto no. 4).

\section{Arti dan Maksud Seni Hias pada Masjid Besar Kauman}

Islam tidak melarangan hal-hal yang berkaitan dengan seni hias. Sebab di dalam Islam terdapat ajaran yang mengatur tentang seni hias. Di dalam Al-Qur'an Surat Al-A'raaf ayat 32 dinyatakan bahwa katakanlah: "Siapakah yang mengharamkan perhiasan dari Allah yang telah dikeluarkan-Nya untuk hamba-hamba-Nya..." (Q.S. 7:32). Dengan demikian dapat dikatakan bahwa potongan ayat tersebut dapat dikaitkan dengan seni hias dan Islam tidak mengharamkan. Hanya saja ada syaratnya yaitu bahwa seni hias tersebut harus tidak berbentuk makhluk hidup atau patung. Hal ini untuk menjaga agar tidak menimbulkan kemusyrikan, sehingga Islam melarang hiasan yang berupa patung dan makhluk bernyawa. Dengan demikian Islam mengharamkan dalam rumah tangga Islam ada patung di dalamnya, apalagi di dalam sebuah masjid. Sebab adanya patung di dalam rumah menyebabkan malaikat akan menjauhi numah tersebut, padahal malaikat akan membawa rahmat bagi seisi rumah (Qardhawi, 1982). Hal ini sesuai dengan sabda Nabi Muhammad saw yang mengatakan bahwa: "Sesungguhnya Malaikat tidak akan masuk terhadap suatu rumah yang di dalamnya terdapat patung" (H.R. Buchari dan Muslim). Nabi Muhammad saw juga bersabda: "Barang siapa membuat gambar (patung) nanti di hari kiamat dia akan dipaksa untuk meniupkan roh padanya, padahal selamanya dia tidak akan bisa meniupkan roh itu" (H.R. Buchari).

Dengan adanya peraturan serta larangan tersebut, di dalam Islam tidak mengenal adanya seni hias yang berupa patung serta motif manusia maupun binatang. Kemudian untuk menjembatani antara larangan tersebut dengan kebutuhan akan seni hias Islam secara umum (meliputi seni hias dalam bentuk manusia dan hewan) maka dibuatlah suatu seni hias rekayasa. Selanjutnya di dalam perkembangan seni hias Islam, seni hias rekayasa tersebut di dalam Ilmu Arkeologi dikenal dengan istilah 
stiliran. Yang dimaksud dengan stiliran adalah seni hias yang menggambarkan suatu bentuk makhluk hidup dengan cara disamarkan agar tidak kelihatan bentuk aslinya tanpa memperhatikan secara seksama.

\section{A. Wajikan}

Kata wajikan berasal dari kata dasar wajik yang mendapat akhiran an. Wajik diambilkan dari nama sejenis makanan yang dibuat dari beras ketan dengan memakai gula kelapa, sehingga warnanya menjadi merah tua. Dinamakan wajikan karena bentuknya seperti irisan wajik atau belah ketupat sama sisi (lihat gambar no. 1). Selain kata wajikan ada pula yang menyebut dengan istilah hiasan sengkulunan. Istilah ini untuk menyebut motif batik yang bentuknya juga belah ketupat (Ismunandar, 1987).

\section{B. Praba}

Praba berasal dari bahasa Kawi atau Sanskerta yang berarti sinar atau cahaya. Praba atau bodhong merupakan hiasan yang berada di belakang atau punggung seorang raja. Khusus untuk hiasan tradisional Jawa yang dimaksud dengan praba adalah pahatan atau ukiran yang menggambarkan sinar atau cahaya. Dilihat secara fisik praba digambarkan seperti ekor burung merak yang sedang "ngigel" yaitu membentangkan ekornya sehingga dapat tegak luns untuk dapat selalu kelihatan bersinar (lihat gambar no. 2). Hiasan ini di Masjid Besar memakai bentuk yang agak berbeda, yaitu menyerupai tlacapan yang terdiri atas tiga buah lancipan. Tetapi walaupun begitu mempunyai arti dan fungsi yang tidak jauh berbeda.

Hiasan ini pada umumnya berwarna kuning keemasan yang dibuat dari bahan prada (bubukan emas). Tetapi untuk bangunan-bangunan tua (misalnya bangunan Bangsal Tamanan Kraton Yogyakarta) mempunyai hiasan praba yang berwarna hijau, biru, dan merah yang disungging. Ragam hias ini selain dipahatkan pada tiang-tiang yang terapat di Bangsal Tamanan, juga ditemukan di Bangsal Kencana dan Bangsal Witana Kraton Yogyakarta (Ismunandar, 1987).

Seperti telah disebutkan di atas, bahwa kata praba berarti sinar atau cahaya. Dengan demikian maksud dan arti pemberian ragam hias ini ialah agar dapat membuat tiangtiang menjadi bersinar atau bercahaya. Belum lagi jika dipahatkan ekor burung merak yang kebulatbulatan, semakin menambah kesan mewah. Di samping itu untuk menambah keindahan keagungan tiang-tiang besar dan berwarna gelap tersebut (Ismunandar, 1987).

\section{Tlacapan}

Kata tlacapan berasal dari kata dasar tlacap, yang mendapat akhiran an yang berarti memakai tlacap. Hiasan ini menggambarkan sinar matahari atau sinar yang berkilauan. Selain itu, ada orang yang menyebut dengan istilah sorotan. Namun yang pokok hiasan semacam ini mengandung arti kecerahan atau keagungan. 
Selanjutnya berkaitan dengan pewarnaan bisa kuning emas polos atau sunggingan dari warna tua ke warna yang muda hingga menjadi warna yang putih. Setelah dilukis atau dipahat, hiasan tlacapan dapat ditempatkan pada pangkal dan ujung balok kerangka bangunan seperti dhadhapeksi, blandar, sunduk, pengeret, ander, santen, dan juga saka santen (Ismunandar, 1987).

\section{Kaligrafi}

Hiasan kaligrafi yang terdapat di Masjid Besar Kauman Yogyakarta merupakan kaligrafi yang telah distilir. Maksudnya adalah hiasan yang terdiri atas raangkaian beberapa huruf Arab yang disamarkan. Artinya bahwa jika hiasan ini tidak diperhatikan dengan seksama, tidak akan dapat diketahui dengan jelas bahwa hiasan tersebut merupakan rangkaian dari huruf-huruf Arab yang mengandung maksud dan arti. Setelah diteliti, hiasan kaligarfi yang terdapat di masjid ini mempunyai dua (2) makna. Kedua macam makna tersebut adalah:

1. Kelompok ini merupakan hasil campuran antara hiasan yang terdapat pada tiang dan umpak batu di Serambi Masjid Besar Kauman Yogyakarta. Tulisan yang terdapat pada kedua media tersebut (tiang dan umpak) merupakan rangkaian kata yang terdiri atas beberapa huruf, yaitu mim, khak, mim, dan dal. Keempat huruf tersebut merupakan singkatan atau kependekan dari kata muhammad. Kata ini dimaksudkan untuk mengagungkan nama Nabi Muhammad s.a.w (Ismunandar, 1987).

2. Kelompok ini merupakan hiasan yang terdapat pada tiang di Serambi Masjid Besar Kauman Yogyakarta. Tulisan yang terdapat pada tiang tersebut merupakan rangkaian kata yang terdiri atas beberapa huruf, yaitu mim, khak, mim, dal, rak, sin, wawu, lam, alif, lam, lam, dan tak. Keseluruhan huruf tersebut merupakan singkatan atau kependekan dari kata muhammad rasulullah. Kata ini dimaksudkan untuk menyebutkan atau menyatakan bahwa nama Nabi Muhammad s.a.w adalah rasul atau utusan Allah ((Ismunandar, 1987).

\section{E. Buah Waluh}

Kata waluh atau waloh tidak jauh berbeda dengan bunyi kata Allah. Walaupun begitu, diwujudkan berupa hiasan buah waluh atau labu sebagai lambang kata Allah (Ismunandar, 1987). Hal ini dimaksudkan jika orang melihat hiasan ini (buah waluh) sebelum memasuki masjid agar selalu ingat dengan Allah swt sebagai sang pencipta.

\section{F. Hiasan-hiasan lain}

Pada dasarnya hiasan yang terdapat pada mimbar, maqsura, mihrab, dan di bawah pengeret terdiri atas sulur-suluran, ceplok bunga, dan ornamen pepohonan. Secara umum hal tersebut merupakan ragam hias tumbuh-tumbuhan. Ragam hias tumbuhtumbuhan ini di Indonesia dikenal sejak periode klasik. Pada seni hias Islam di beberapa kekunoan Islam di pantai utara Jawa, ragam hias tersebut selain digambarkan berdiri sendiri, juga digunakan untuk menyamarkan motof-motif lain, 
khususnya motif makhluk hidup (Abbas, 1983). Memang pada kenyataannya di dalam ruang inti Masjid Besar Kauman Yogyakarta ini motof hias yang dominan adalah tumbuh-tumbuhan. Sedangkan motif hiasan yang lain berupa kaligrafi yang ditampilkan dalam bentuk stiliran maupun dalam bentuk yang asli tulisan Arab.

\section{Kesimpulan}

Berdasarkan atas uraian-uraian di atas, di bawah ini akan dikemukakan beberapa hal yang berkaitan dengan makalah ini.

1. Seni hias merupakan salah satu alat yang dapat digunakan untuk memberikan pesan-pesan tertentu bagi sesama manusia. Khususnya pesan yang berkaitan dengan semangat keagamaan.

2. Seni hias yang ditampilkan di dalam Masjid Besar Kauman Yogyakarta, baik pada ruang serambi maupun ruang inti tidak menggunakan seni' hias makhluk hidup. Hal ini sesuai dengan ajaran agama Islam. Seni hias yang terdapat di masjid ini berupa wajikan, praba, tlacapan, kaligrafi, dan sulur-suluran serta bunga dan buah waluh. 


\section{KEPUSTAKAAN}

Abbas, Novida. 1983. Motif-motif Binatang Pada Beberapa Kekunaan Islam Di Sepanjang Pantai Utara Jawa. Yogyakarta: Skripsi Sarjana pada Jurusan Arkeologi, Fakultas Sastra, Universitas Gadjah Mada.

Al-Qur'an dan Terjemahnya. 1978/1979. Jakarta: Departemen Agama Republik Indonesia, Pelita II.

Atmodjo, Junus Satrio (penyunting). 1999. Masjid Kuno Indonesia. Jakarta: Direktorat Perlindungan dan Pembinaan Peninggalan Sejarah dan Purbakala, Direktorat Jenderal Kebudayaan, Departemen Pendidikan dan Kebudayaan Republik Indonesia.

Chawari, Muhammad. 1989. Pasang Surut Masa Perkembiangan Pembangunan Masjid Besar Kauman Yogyakarta, Studi Berdasarkan Sumber Prasasti. Yogyakarta: Skripsi Sarjana pada Jurusan Arkeologi, Fakultas Sastra, Universitas Gadjah Mada.

Encyclopaedia Britanica Vol. 16. 1961. London: William Benton Publisher.

Ismunandar, K.R. 1987. Joglo Arsitektur Rumah Tradisional Jawa. Semarang: Effhar Offset. Cetakan Kedua

Qardhawi, Muhammad Yusuf. 1982. Halal dan Haram Dalam Islam. Surabaya: Bina Ilmu. Terjemahan Muhammad Hamidy.

Shadily, Hassan. 1982. Ensiklopedi Indonesia 3. Jakarta: Penerbit Ichtiar Baru - Van Hoeve hlm. 1298.

Saptono, Nanang. 1990. Unsur Ajaran Sufi Pada Masjid Agung Demak (Tinjauan Terhadap Seni Hias dan Seni Bangun). Yogyakarta: Skripsi sarjana pada Jurusan Arkeologi, Fakultas Sastra, Universitas Gadjah Mada. 


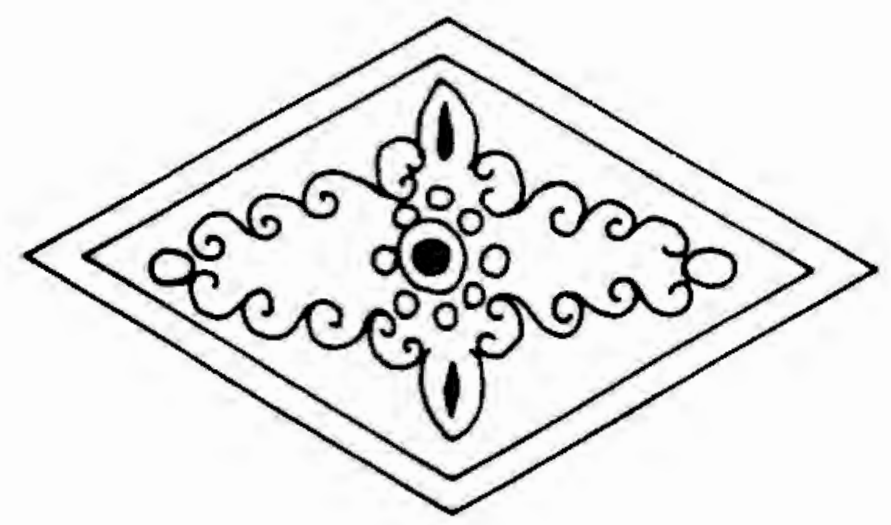

Gambar 1. Hiasan wajikan dengan bingkai rangkap dua

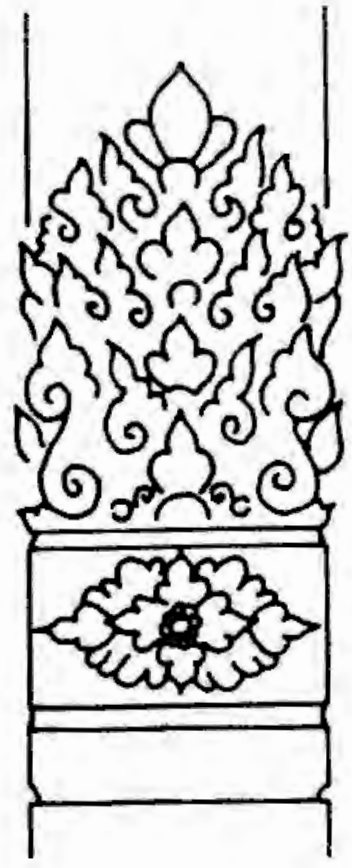

Gambar 2. HIasan praba yang terdapat pada tiang 


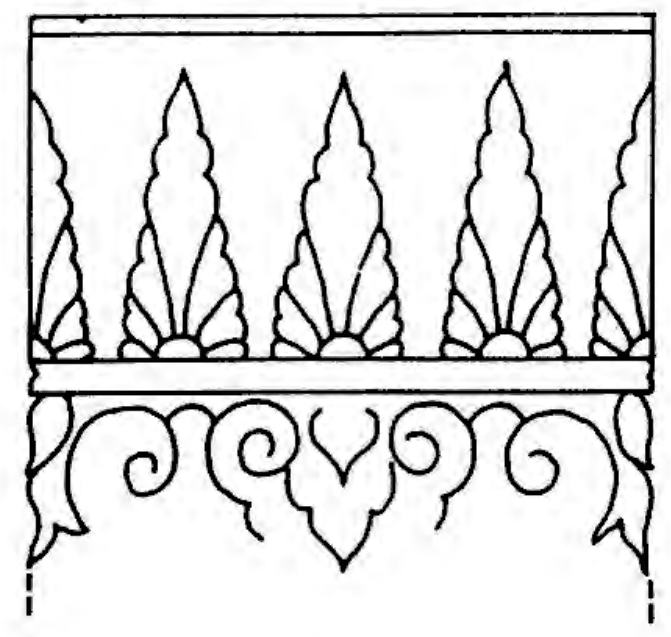

Gambar 3. Bentuk hiasan tlacapan secara umum
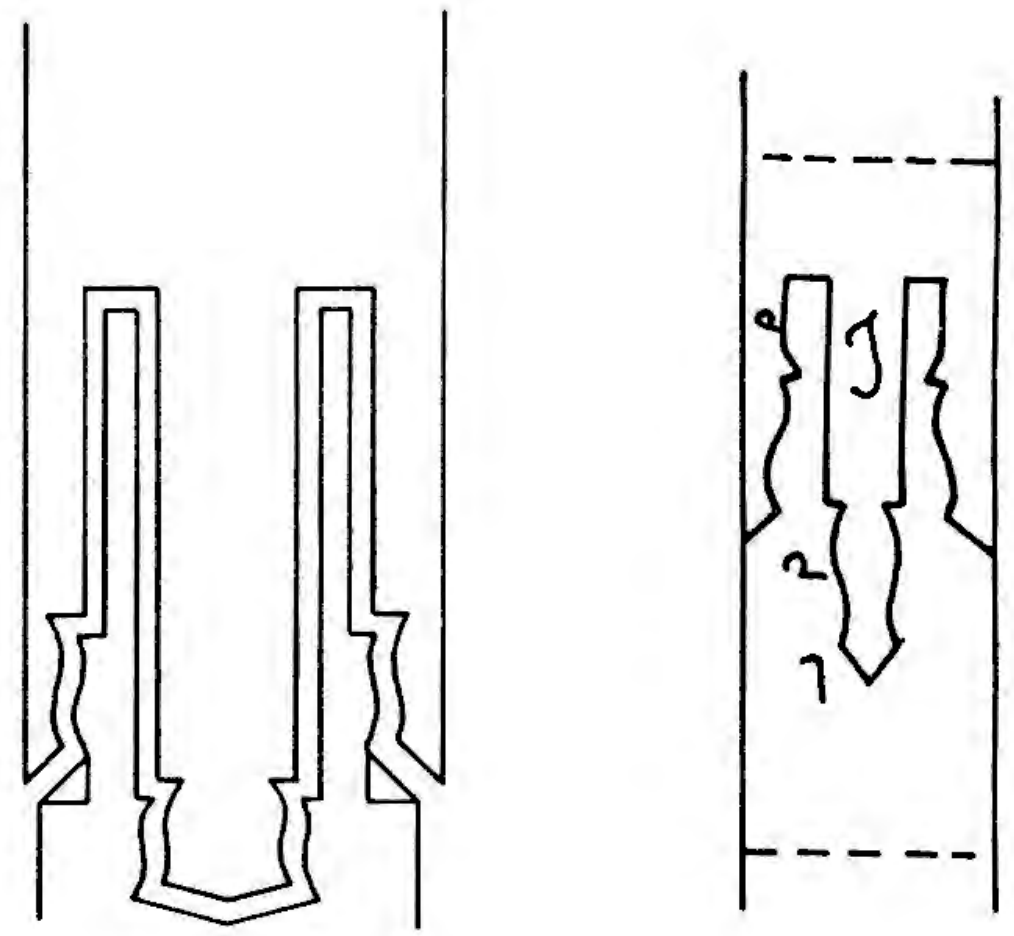

Gambar 4. Salah satu hiasan kaligrafi dengan bentuk seperti panah yang menghadap ke bawah 


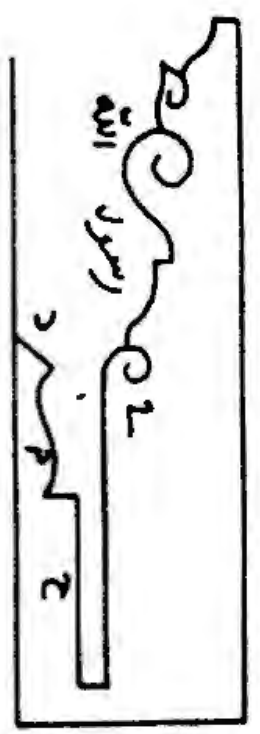

Gambar 5. Salah satu bentuk hiasan kaligrafi yang menyerupai telunjuk jari

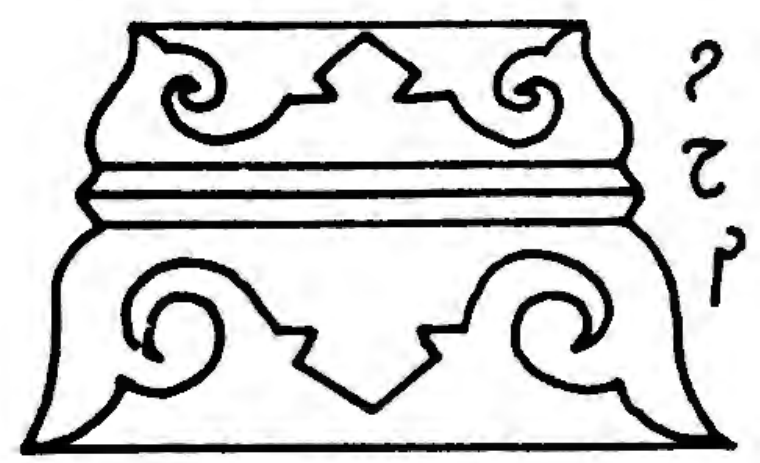

Gambar 6. Salah satu bentuk hiasan kaligrafi pada umpak tiang 


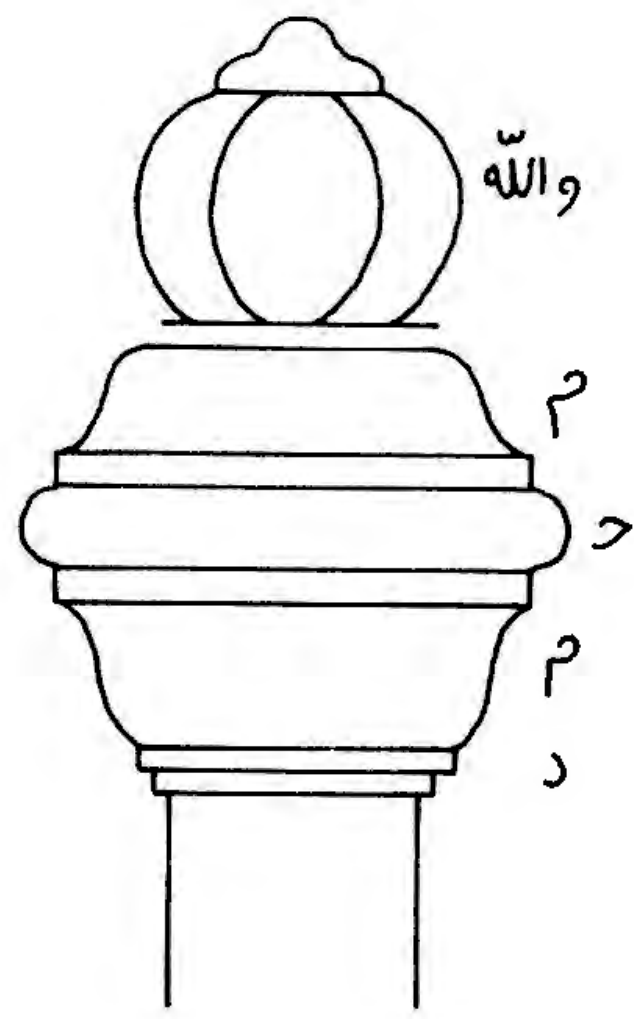

Gambar 7. Hiasan mirip buah waluh dalam bentuk tiga dimensi 


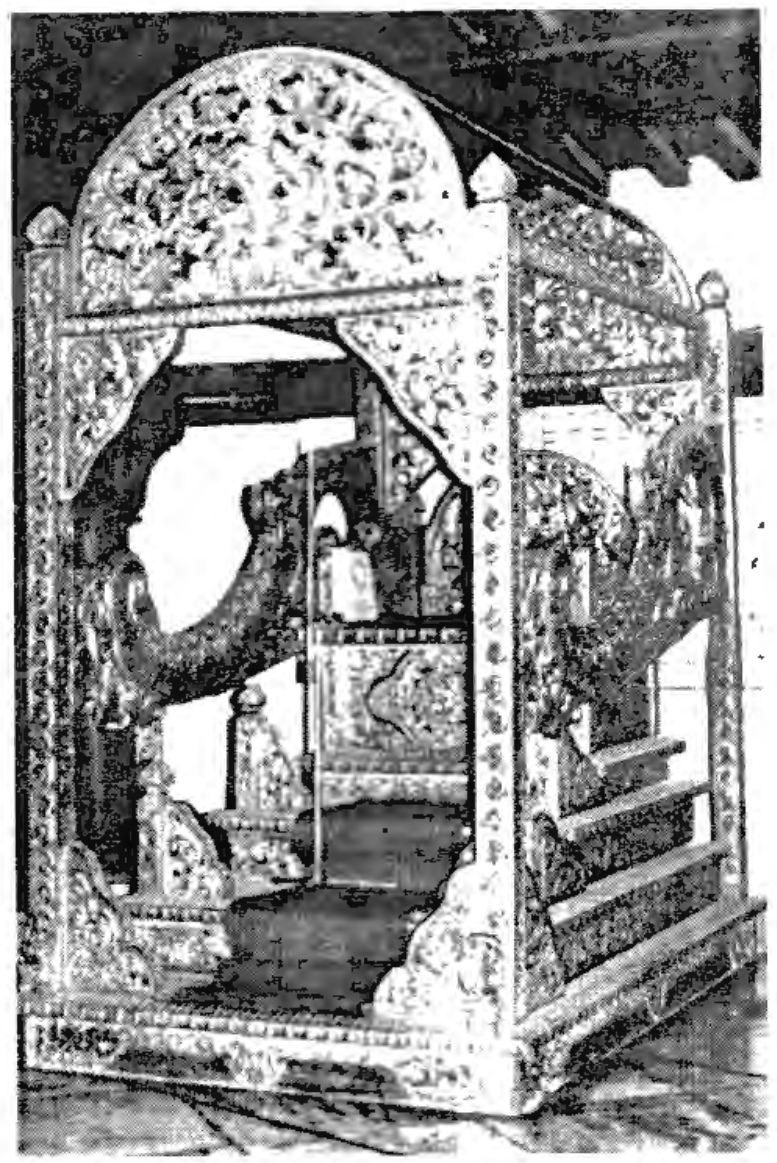

Foto 1. Hiasan sulur-suluran pada mimbar di dalam ruang inti masjid

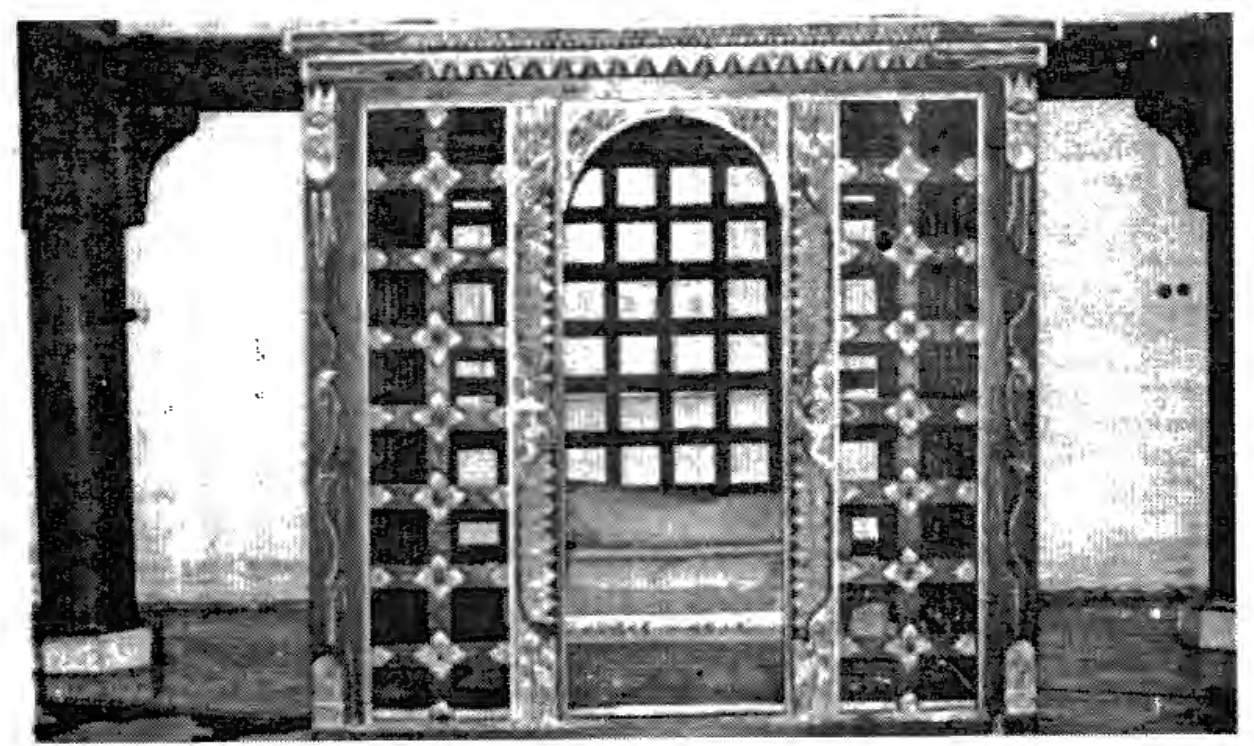

Foto 2 . Hiasan pada maqsura yang terdapat di dalam ruang inti masjid 


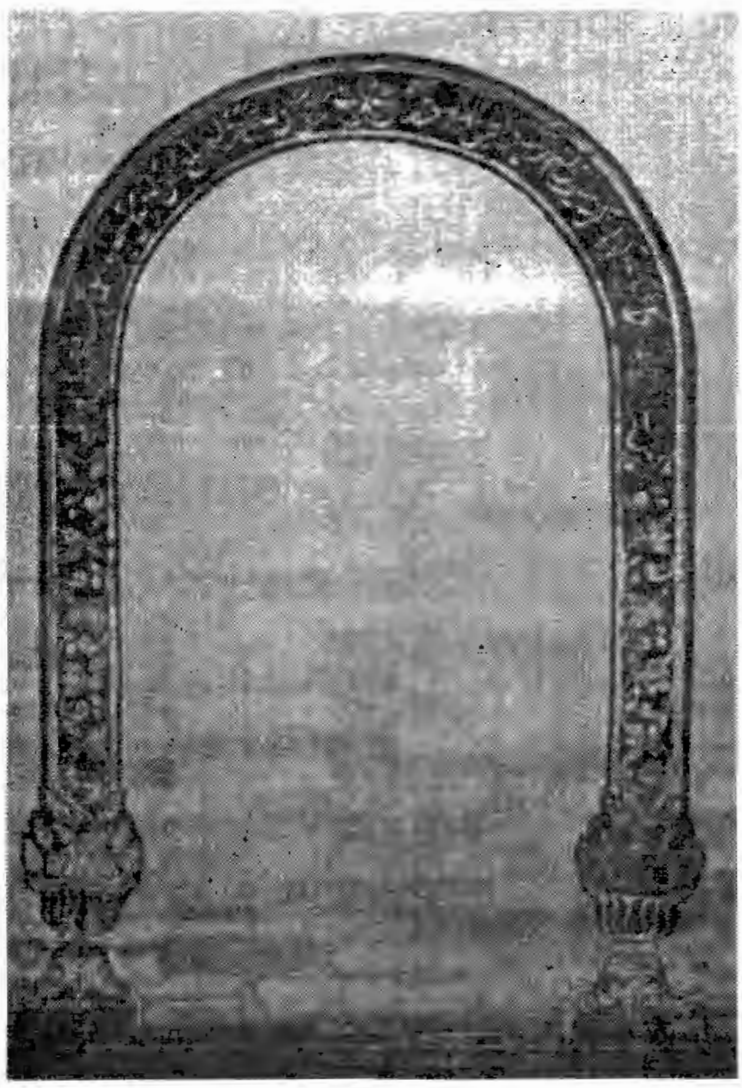

Foto 3. Hiasan pepohonan yang terdapat di kanan-kiri mihrab

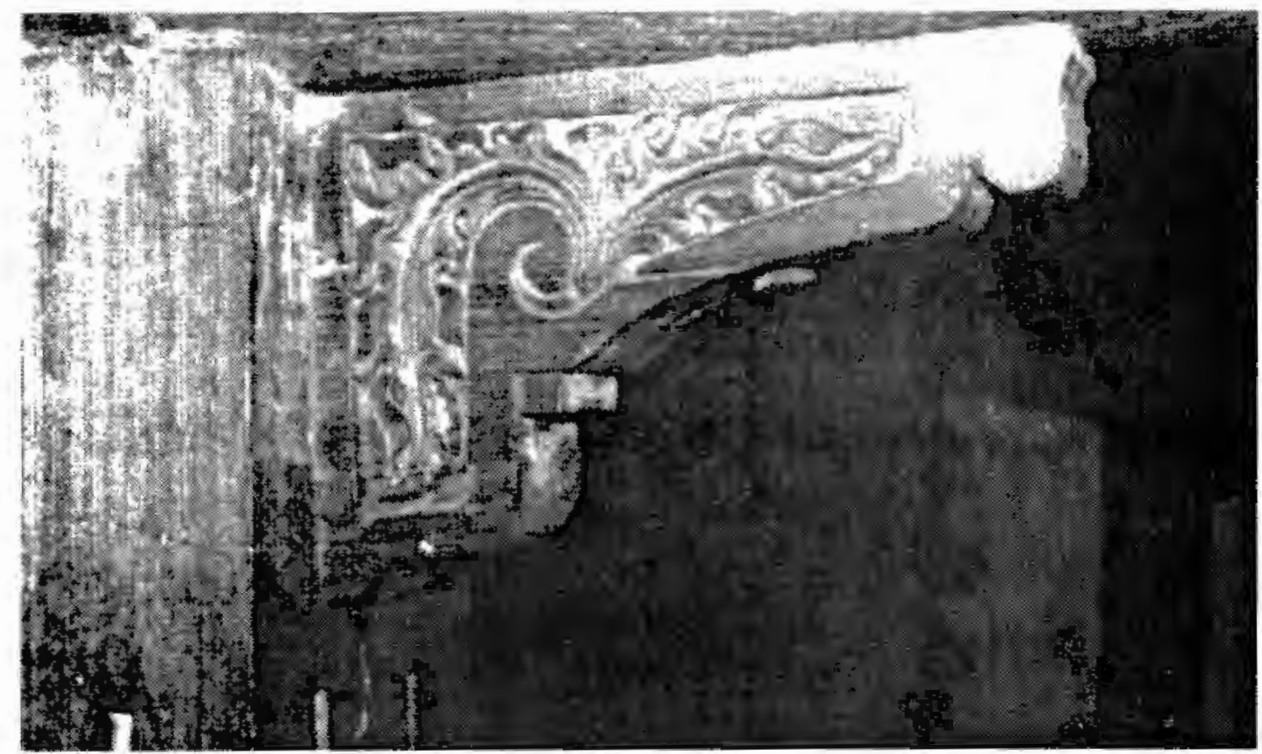

Foto 4. Hiasan di bawah pengeret di dalam ruang inti masjid 